San Jose State University

SJSU ScholarWorks

Master's Projects

Master's Theses and Graduate Research

Spring 5-2020

\title{
Credit for Prior Learning among Student Veterans across Selected Campuses of University of California and California State University: A Managerial Audit
}

Janani Chandrasekar

San Jose State University

Follow this and additional works at: https://scholarworks.sjsu.edu/etd_projects

Part of the Education Policy Commons, Military and Veterans Studies Commons, Policy Design, Analysis, and Evaluation Commons, and the Public Administration Commons

\section{Recommended Citation}

Chandrasekar, Janani, "Credit for Prior Learning among Student Veterans across Selected Campuses of University of California and California State University: A Managerial Audit" (2020). Master's Projects. 945. DOI: https://doi.org/10.31979/etd.yys8-rpss

https://scholarworks.sjsu.edu/etd_projects/945

This Master's Project is brought to you for free and open access by the Master's Theses and Graduate Research at SJSU ScholarWorks. It has been accepted for inclusion in Master's Projects by an authorized administrator of SJSU ScholarWorks. For more information, please contact scholarworks@sjsu.edu. 
Credit for Prior Learning among Student Veterans across Selected Campuses of University of

\title{
California and California State University: A Managerial Audit
}

\author{
By \\ Janani Chandrasekar

\begin{abstract}
A Thesis Quality Research Project
Submitted in Partial Fulfillment of the

PUBLIC ADMINISTRATION
\end{abstract} \\ Requirements for the Master's degree in
}

Frances Edwards, Ph.D.

The Graduate School

San Jose State University.

May 2020 


\section{ACKNOWLEDGEMENTS}

I want to thank a few people whose contributions were invaluable to this project. First, I want to thank Dr. Leonard Lira for sowing the seed of this topic in my head and for always being a sounding board to my ideas. You pulled me out of obscurity and for that I will always be grateful! I want to thank Dan Goodrich for talking to me about his experience and giving me the idea of conducting a survey to understand the prevalence of this issue. I would also like to thank Robert Davis for his time and patience in answering all my questions pertaining to CPL at SJSU. Finally, I want to thank Dr. Frances Edwards, my advisor for always setting the highest of standards and advising me through this process.

While I'm at it, I want to acknowledge the contribution of my invisible army. Appa and Hari for always asking me reach for the stars and never letting me quit; Arjun for being the rock that held our family together these last two years, while providing me with unflinching support; ladies of my tribe (Gheerdhu, Vas, Jack, Mayuri, and Priyanka) who have held my hand in my journey; and finally, Amma: this one is for you. 


\section{TABLE OF CONTENTS}

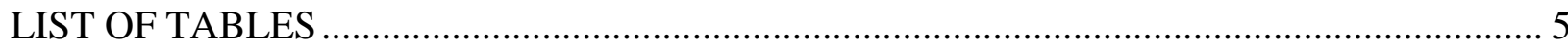

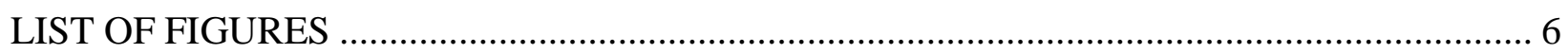

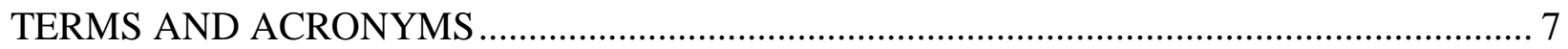

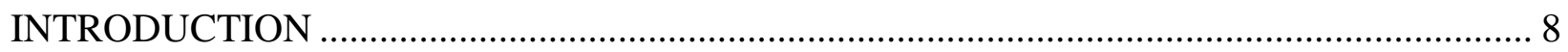

Research Question .............................................................................................. 8

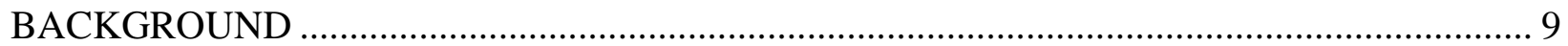

Servicemen's Readjustment Act of 1944: The GI Bill ................................................... 9

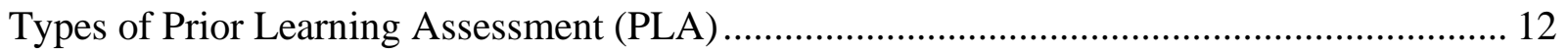

Enlisted Personnel's Military Training and Alignment with College Work ......................... 13

Multi-State Collaborative on Military Credit (MCMC) ................................................. 16

Prior Learning Assessment within the California State University System ......................... 17

Prior Learning Assessment within the University of California System ............................. 18

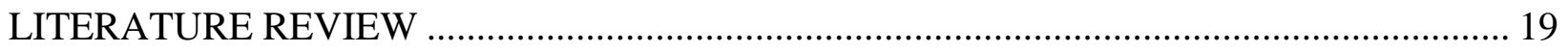

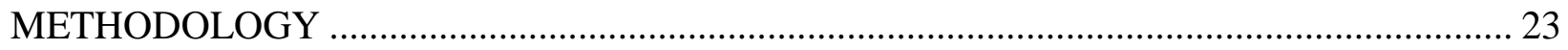

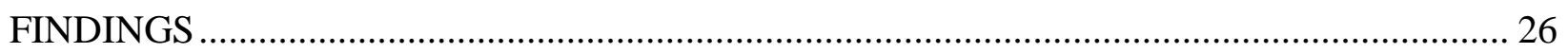

Part One: Process Followed to Award Credit for Prior Learning on Selected UC And CSU

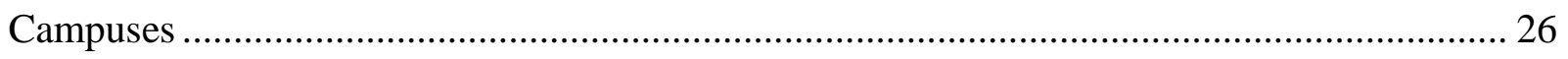

Part Two: Survey Administered to Student Veterans at SJSU ......................................... 30

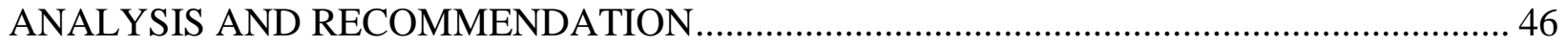


Analysis of UC Policy to Award Credit for Military Training …........................................ 46

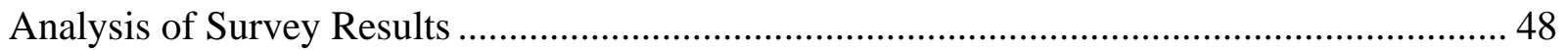

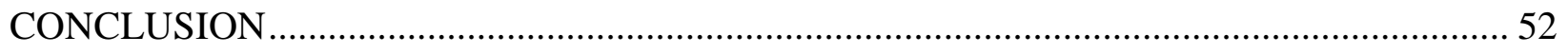

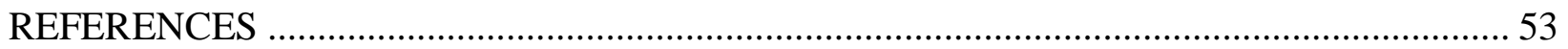

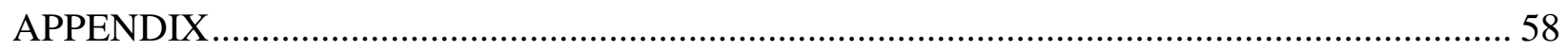




\section{LIST OF TABLES}

Table A: Questionnaire mailed to Articulation Officers..................................................... 24

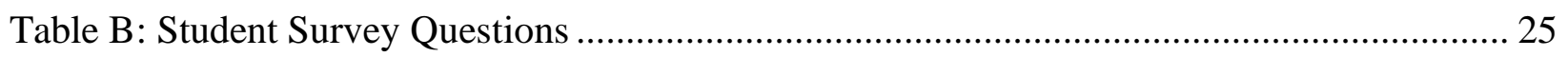

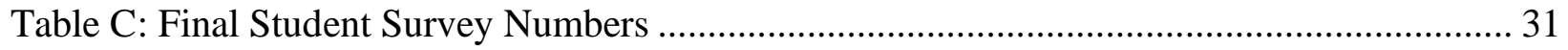

Table D: Distribution based on Military Branch ............................................................ 32

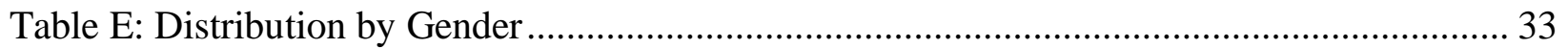

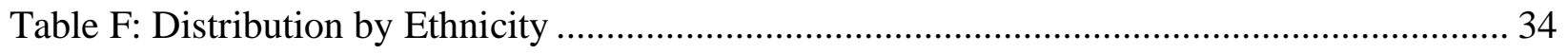

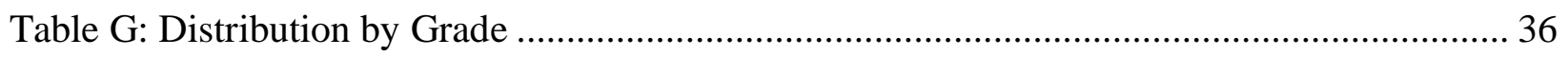

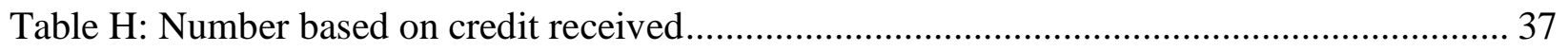

Table I: Number of students receiving credits versus number of students who should have received credits based on ACE recommendations: Army .......................................... 40

Table J: Number of students receiving Credits versus number of students who should have received credits based on ACE recommendations: Marine Corps ................................. 42

Table K: Number of students receiving credits versus number of students who should have received credits based on ACE recommendations: Navy 


\section{LIST OF FIGURES}

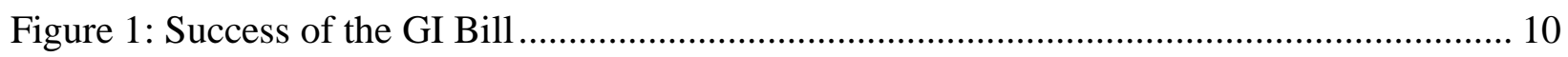

Figure 2: Distribution of Student Veterans by Discipline ............................................... 11

Figure 3: Distribution based on Military Branch ................................................................. 32

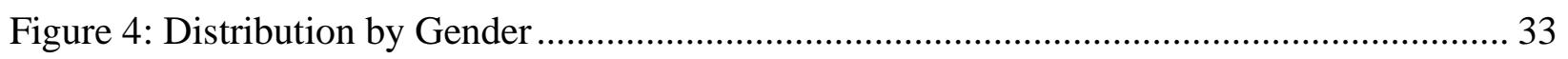

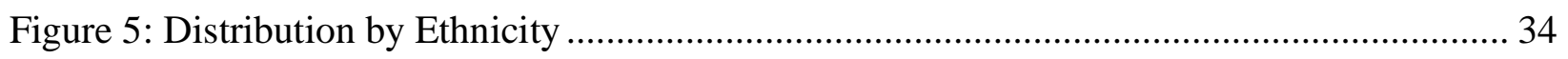

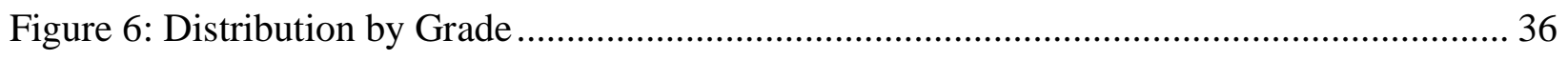

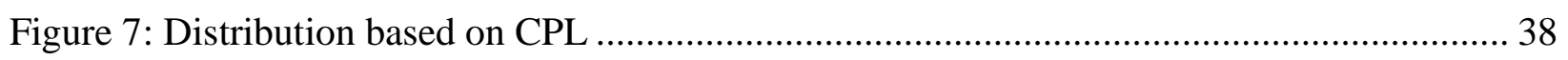

Figure 8: Number of students receiving credits versus number of students who should have received credits based on ACE recommendations: Army ......................................... 41

Figure 9: Number of students receiving credits versus number of students who should have received credits based on ACE recommendations: Marine Corps................................. 43

Figure 10: Number of student veterans receiving credits versus number of students who should have received credits based on ACE recommendations: Navy 


\section{TERMS AND ACRONYMS}

ACE: American Council on Education

CAEL: Council for Adult \& Experiential Learning

CCAF: Community College of Air Force

CPL: Credit for Prior Learning

CSU: California State University

Grade: Enlisted person's pay scale (E1 to E9)

GE: General Education

IRB: Institutional Review Board

JST: Joint Services Transcript

MCMC: Multi-State Collaborative on Military Credit

MCU: Marine Corps University

MOS: Military Occupational Specialty

PE: Physical Education

PLA: Prior Learning Assessment

Rank: Military Officer's pay grade (W1 to W5; O1-O10)

SDSU: San Diego State University

SJSU: San José State University

UC: University of California

UCSC: University of California, Santa Cruz

UCSD: University of California, San Diego

VRC: Veterans Resource Center 


\section{INTRODUCTION}

Credit for Prior Learning (CPL), also known as, Prior Learning Assessment (PLA) is defined as the "method adopted by post-secondary institutions to award academic credit to a student's knowledge and skills provided they are determined to be college-level learning" (Education Commission on States [Ed. Comm on States], 2018). One major faction of students applying for CPL is veterans; their military training and coursework can be applied toward college credits, which leads to saving time and resources spent on their tuition.

A study by the Council for Adult \& Experiential Learning (CAEL) found that earning 15 college credits can save $\$ 1,600$ to $\$ 6,000$ in tuition costs. In addition to this, PLA students saved anywhere between 2.5 months to 10 months of time in earning their college degrees. The study pointed to the higher degree-earning-rates among students with CPL as opposed to their counterparts without such credit (CAEL, 2010).

\section{Research Question}

"What variations are observed in the implementation of Credit for Prior Learning (CPL) for student veterans across different public universities in California? What gaps, if any, exist in SJSU's CPL program when compared to other campuses, and what recommendations can be made to build a more efficient process?" 


\section{BACKGROUND}

Credit for Prior Learning has been recognized by post-secondary institutions since World War I to facilitate the transition of returning veterans into civilian life. Higher education institutions were looking to provide avenues for veterans to showcase their skills and training gained during their service and apply it to their civilian transition. CPL was used as one of the tools to increase veteran enrollment in higher education (American Council on Education, 2015).

\section{Servicemen's Readjustment Act of 1944: The GI Bill}

In the context of veterans, the recognition of prior skills and training was different from others because of the Servicemen's Readjustment Act of 1944. Commonly known as the GI bill, it established premise system for covering tuition costs and associated expenses for veterans (US Department of Veterans Affairs [US DoVA], 2019). The legislative intent behind the GI bill was to assist the reintegration of veterans into society after the failure to do so for World War I veterans led to widespread dissatisfaction (US DoVA, 2019). The post-9/11 Veterans Assistance Educational Act, or the post-9/11 GI Bill, which was passed in 2008, was the sixth version of the bill passed by Congress, and is active today (US DoVA, 2019). It provides assistance to veterans who have served on active duty for 90 or more days since Sept. 10, 2001(US DoVA, 2019). The post-9/11 GI bill allows veterans to transfer any unutilized benefit to their family (namely, spouse and children). The costs covered by the bill include tuition, monthly housing allowance, books and supplies, and transportation. Veterans and their family members have been using the benefits of GI bill and the extent of their benefits is dependent on their years of active service post-9/11.

The intent of the GI bill was to ensure that war veterans are able to seamlessly integrate back into civilian life with the help of certain resources. The law sought to make higher 
education affordable, accessible and enhance educational attainment among veterans (American Council on Education [ACE], 2015). According to a statistic provided in the National Veteran Education Success Tracker (NVEST) report by Student Veterans of America (SVA) in 2017, the GI bill has helped over 340,000 student veterans who have earned nearly 450,000 post-secondary certificates or degrees. Figure 1 provides an overview of the success of the Post 9/11 GI bill, six years after it was passed.

The report predicted that the number of veterans earning degrees and certifications using the Post-9/11 GI Bill was expected to increase to 1.4 million in the next decade (Student Veterans of America [SVA], 2017).

Figure 1: Success of the GI Bill

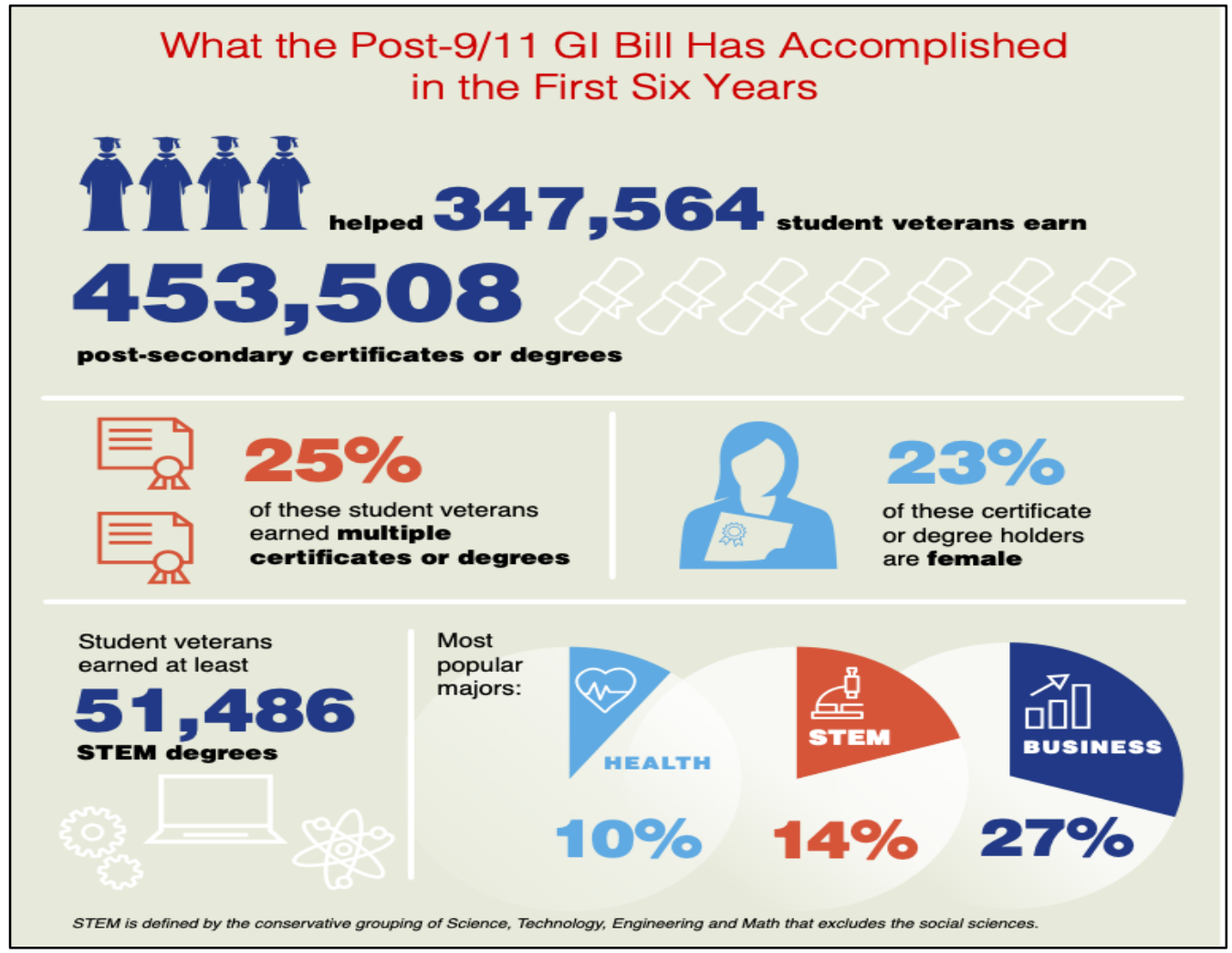

(Source: Student Veterans of America, 2017) 
Figure 2 provides a graphical description of the number of veterans earning degrees in different disciplines with business, management and marketing degrees being the most popular choice.

\section{Figure 2: Distribution of Student Veterans by Discipline}

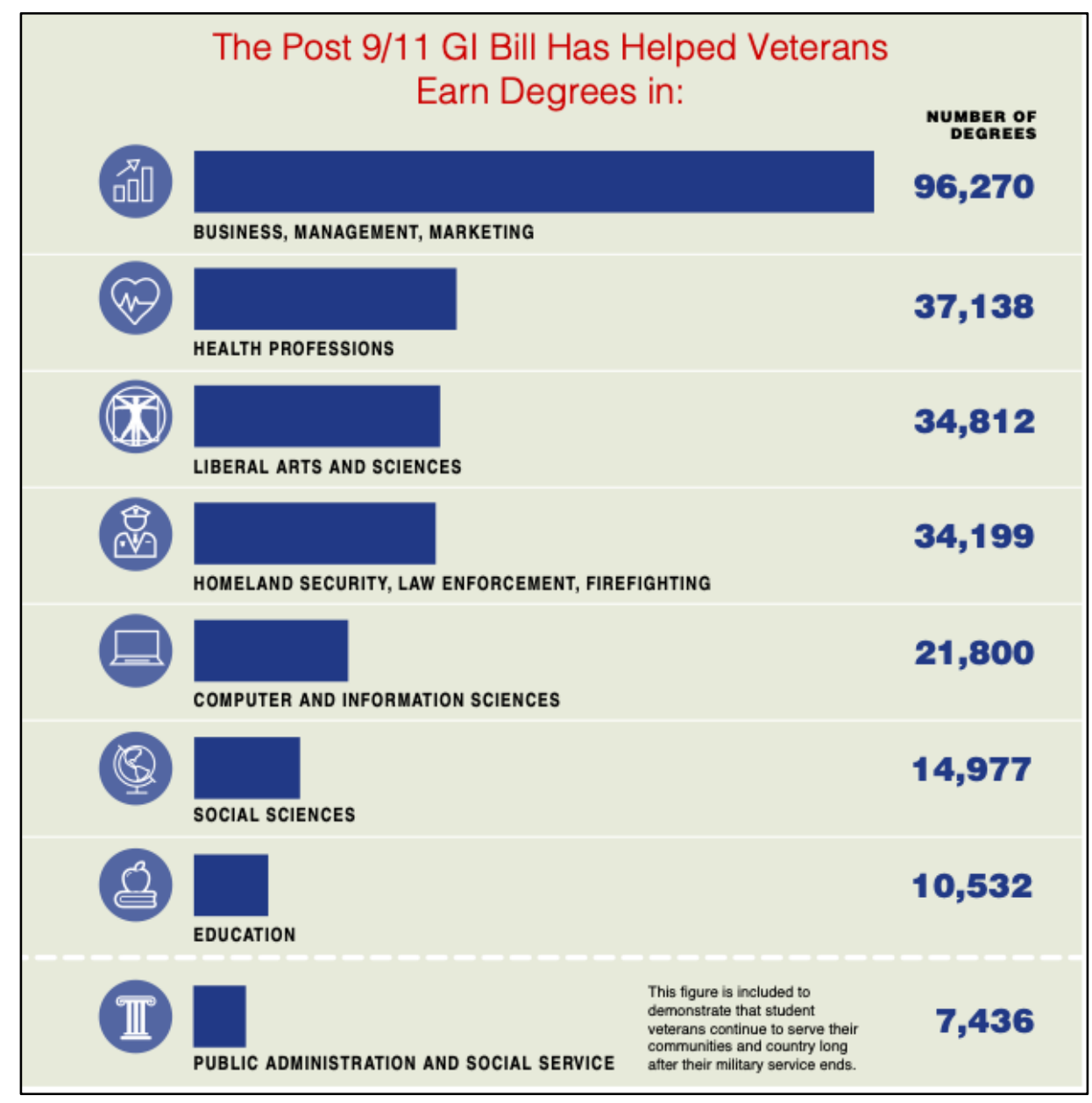

(Source: Student Veterans of America, 2017)

\section{American Council on Education (ACE) and the "Military Guide"}

The American Council for Education, formerly known as the Emergency Council on Education, was established in 1918 to help the government, military, and higher education institutions with the educational requirements and transition of World War I veterans into civilian life (ACE, 2015). ACE published the first "Guide to Evaluation of Educational Experiences in the Armed Services" in 1944, 
which served as a tool for determining the number of college credits that could be awarded to military courses and training. The guide was later transferred to the online "Military Guide" in 2006.

The Military Guide is a major resource used today by campuses granting CPL and is used to determine the credit equivalent of military courses, training and occupations to college-level courses. According to ACE, "The Military Guide presents credit recommendations and detailed summaries for formal courses and occupations offered by all branches of the military." In addition to course evaluations, ACE provides occupational evaluations that identify the skills, competencies and knowledge developed during their professional assignments in the military (ACE, 2019). The recommendations have been widely accepted by universities because of the similarities between military courses and traditional postsecondary education programs. The Military Guide's purpose is to maximize the learning outcomes achieved in the military and translate the same to college credits, thereby helping students achieve their final goal of graduation.

\section{Types of Prior Learning Assessment (PLA)}

While understanding the process of PLA, it is essential to be aware of the different types of PLA. With respect to student veterans, the following four types have been identified (Multi State Collaborative on Military Credit, 2016):

1. Transfer Guides for Military Training and Transcripts: Schools have their own set of guidelines to determine the credit awarded for courses shown in the Joint Service Transcript (JST).

2. Portfolio Assessments: Based on a document written by students on their occupational role in the military called the portfolio, student veterans can receive credit for their experiences and skills. There are some online portfolio assessment tools like CAEL’s “Learning Counts” (MCMC, 2016). 
3. Program Evaluations: This is done to evaluate any certifications or training that a student veteran has undergone in the military and which may be translated to college credits through an accelerated/bridge program. This helps save time and also helps evaluate the competency of a student veteran in that particular skill set.

4. Customized Exams and Standardized Testing: Some colleges, in order to test the competency of veterans applying for CPL, conduct exams to determine if the knowledge of the student is on par with the learning outcome established by faculty on campus. There are standardized exams like College Level Examination Program (CLEP) and the DANTES Subject Standardized Tests (DSST) recognized by certain campuses as a measure of competency (MCMC, 2016).

Schools usually use a combination of the above to determine the number of credits to be awarded to a student. For example, student veterans are awarded three credits towards Physical Education (PE) for the training received in the military at San José State University and CLEP exam scores are considered as well.

\section{Enlisted Personnel's Military Training and Alignment with College Work}

After enlistment, new recruits undergo basic training for a specific period of time, which varies from one military branch to another (Today's Military, n.d.). Following the successful completion of the basic training, enlisted personnel are given a specific Military Occupational Specialty (MOS) code, and training for the MOS is given either on the job, or at specialized schools (Today's Military, n.d.). Specialized schools facilitate academic learning and skills aligned to a candidate's MOS (Stoval, 2018).

\section{Air Force}


Basic Military Training in the Air Force is eight and half weeks, conducted at Lackland Air Force Base in San Antonio, Texas (U.S. Air Force, n.d.). After the completion of basic training, every candidate is assigned an Air Force Specialty Code (AFSC) and the AFSC will determine the technical school that a candidate will attend (Stoval, 2018). The AFSC determines the length of time spent at technical school. The technical school will equip servicemembers with the required skillset for the AFSC, and these courses generate credit because they have college equivalent courses (Airman Vision, n.d.).

\section{Army}

Enlisted Army recruits start with the Basic Combat Training (BCT) lasting about 10 weeks, which is conducted at Fort Benning, Georgia; Fort Jackson, South Carolina; Fort Leonard Wood, Missouri and Fort Sill, Oklahoma (U.S. Army, n.d). The BCT is followed by additional phases of training called Advanced Individual Training (AIT) based on an individual's MOS (U.S. Army, n.d.). AIT equips candidates with skills required to perform the job assigned, and provides handon training along with field instruction (U.S. Army, n.d.). The Army also offers a wide variety of courses in leadership, tactical, technical, and physical development at their specialty school for soldiers looking to advance their careers (U.S. Army, n.d.).

\section{Coast Guard}

Basic training in the Coast Guard lasts for eight weeks and takes place at Cape May, New Jersey. Following the basic training, an enlisted candidate will be promoted to an E-2 pay grade (GoCoastGuard, n.d.). After this, every candidate will receive specific academic training based on their MOS [known as rating in the Coast Guard (GoCoastGuard, n.d.)]. The MOS would require either on the job training, also called "striker" program, or formal 'A' school training which will generate academic credit if it has a college equivalent course (GoCoastGuard, n.d.). 
After the highest enlisted grade (E-9) has been achieved, an enlisted member can apply for Officer Candidate School (GoCoastGuard, n.d.).

\section{Marine Corps}

Basic training, known as Recruit Training in the Marine Corps, is a 12 week three-phase training program that takes place at Recruit Training Depot at Parris Island, South Carolina, or Recruit Training Depot at San Diego, California (Military.com, n.d.). After basic training, a candidate progresses to Training Command, which provides training in three specific areas: primary MOS training; career progression MOS training; and specialized skills training (Marines, n.d.).

The College of Enlisted Military Education (CEME) has different schools offering courses targeted to provide the relevant skill set for a candidate's MOS in an academic setting. Some of the schools are the Resident Sergeants School; Resident Career School; and Active Duty Command Sponsored Corporals Course, among others (Marines, n.d.).

\section{Navy}

New recruits in the Navy undergo basic training/recruit training for eight weeks at Great Lakes Naval Training Center, Illinois, following which they are sent to Accession Training, commonly known as A School. A sailor's MOS will determine the location of his/her A School (U.S. Navy, n.d.). This will provide him or her with an opportunity to focus on learning what is needed during a sailor's first tour. The A School is considered to be a continuation of the basic training, and on graduating from A School, a sailor is given his/her first job assignment, and further training is received during the remainder of a sailor's career (U.S. Navy, n.d.). 


\section{Alignment of Military Training with College Credit}

The training provided to enlisted military personnel after the basic training, which is done in an academic setting, can be translated into college-level courses for credit, and this is done with the help of the Joint Services Transcripts (JST) (Marine Corps University, n.d.). The JST serves as a tool by which military schooling and work experience is presented in civilian language (Marine Corps University, n.d.). It also helps in preparing the resumes of service members by explaining their work experience in civilian language and listing academic credits for courses taken in the military (Marine Corps University, n.d.). According to the Marine Corps University website (n.d.), "JST is an academically accepted document approved by the American Council on Education (ACE) to validate a service member's military occupational experience and training along with the corresponding ACE college credit recommendations".

\section{Multi-State Collaborative on Military Credit (MCMC)}

The MCMC is convened by the Midwestern Higher Education Compact (MHEC) which is a legislatively created 501(c)(3) organization based in Minneapolis. The MHEC intends to advance opportunities in higher education in the Midwestern region (About, MHEC, 2020). The Compact serves its member states by maximizing resources, ideas and expertise in providing quality higher education (MHEC, 2020). There are 13 member states from the midwestern region. They are Illinois, Indiana, Iowa, Kansas, Kentucky, Michigan, Minnesota, Missouri, Nebraska, North Dakota, Ohio, South Dakota and Wisconsin. The MHEC proposed the "Multi-State Collaborative on Military Credit" (MCMC) in 2014 to "translate competencies acquired by servicemembers through military training and experiences towards meaningful college credits" (Multi-state Collaborative on Military Credit, MHEC, 2014,pg. 1). The MCMC has recognized three goals that would assist veterans in transitioning to civilian life and helping them complete 
postsecondary degrees. The goals include establishing a network of communication, formal documentation and data collection to promote student success in educational institutions; increasing completion rates of post-secondary education among student veterans by recognizing military training and awarding credits for the same; and providing assistance with transition to civilian life and employment after education (Multi-state Collaborative on Military Credit, MHEC, 2014). As mentioned in the MCMC website, the project is funded by the Lumina Foundation ( $\$ 900,000$ over a three-year period) and by Strada Education $(\$ 200,000$ over a oneyear period) (MHEC, 2020). The MCMC is an example of states and educational institutions taking a closer look at awarding credit for military learning and experiential training obtained during service.

\section{Prior Learning Assessment within the California State University System}

The California State University system does not follow a uniform process for awarding CPL; rather each campus designs a process that suits its needs best. As a result, some campuses actively engage in awarding CPL, while some have not been successful in implementing it. The CSU Executive Order (EO) 1036 (Article 3) states, "Students shall be granted credit ...for completion of formal instruction in non-collegiate settings, (either civilian or military) as recommended by the American Council on Education publication Guide to the Evaluation of Educational Experiences in the Armed Services.” (CSU Policy Stat, 2008). According to this EO, every CSU campus should recognize military training/courses as prescribed in the ACE recommendations.

According to the guidelines on the CSU website, credit is determined based on ACE's Military Guide and by reviewing the JST of the student veteran. The JST will provide 
information on the courses taken during the student's time in the military and also will provide information about his or her occupational specialty.

Universities are streamlining their process of awarding CPL, as it contributes to the CSU Graduation Initiative 2025 by helping veterans graduate successfully and on time. This project performed a managerial audit of CPL performed across universities in California.

\section{Prior Learning Assessment within the University of California System}

University of California has set guidelines to award credit for military training, usually in the area of Physical Education. Depending on the courses taken in the military, possible credit is offered to Military Science and Language courses (Admissions, University of California, 2018). Ultimately, credit awarded is based on the course content, for which each campus requires complete course description and the official transcript. It is important to note that UC does not grant credit based on standardized exams like College Level Examination Program (CLEP) or DANTES Subject Standardized Tests (DSST) (Admissions, University of California, 2018). A report by UC Institutional Research and Academic Planning, published in March 2020 shows that more than half of UC student veteran population is concentrated at three UC campuses: San Diego, UCLA and Berkeley (Undergraduate Outcomes, UC Institutional Research and Academic Planning, 2020). A total of 2,200 student veterans were enrolled in the UC system during the Fall 2018 academic year, according to the same report. 


\section{LITERATURE REVIEW}

With the US military looking at one of its biggest draw-downs anticipated from stations abroad with up to a $25 \%$ reduction in armed service personnel over the next few years (Fickert, 2013), the re-integration of veterans into the civilian sector is a challenge in terms of transitioning from the military into civilian employment, establishing an identity and developing a new lifestyle (Bergman, 2016). It has been observed that obtaining a higher education degree has assisted veterans in setting goals for themselves and has proven to be an avenue for veterans to apply their technical, interpersonal and strategic thinking to civilian life (McNally, 1996).

In order to facilitate their pursuit of higher education, Credit for Prior Learning for military skills and courses encourages veterans to finish their degree and pursue higher education (Bergman, 2014), which appears to be related to higher average earnings; a college degree holder earns $\$ 41,000$ to $\$ 59,000$ per year as compared to a high school graduate who earns $\$ 35,000$ per year (Torpey, n.d.). According to a study by CAEL conducted across 48 campuses on Prior Learning Outcomes in 2008, it was found that $56 \%$ of PLA students earned a post-secondary degree when compared to $21 \%$ of their non-PLA counterparts. Increased academic outcome and lesser graduation time have been the two of the most significant outcomes from the CAEL study. Another factor to consider is the financial implications of PLA on the institution in addition to the student veteran. In her paper examining the financial implication of Prior Learning Assessment, Fonte (2008) throws light on institutions awarding CPL to have higher retention rate coupled with increased admissions (Fonte, 2008). The crux of the paper is that institutions with PLA tend to "win over" non-PLA institutions by the very fact that it is always better to have a student and earn some portion of his or her tuition than not have a student at all (Fonte, 2008). 
The paper demonstrates that students granted CPL tend to stay on in the university to finish their degree as opposed to students who were not recognized for their prior learning.

Since 1954, the American Council for Education (ACE) has been evaluating military courses and occupation portfolios, providing recommendations on the appropriate number of credits for those courses. The content of military courses is evaluated on the basis of their scope, rigor and content (ACE, 2019). The intent of publishing such a guide is to ensure that veterans enrolling in college are granted credit for their experience in the military. Recognizing the need for a translational tool to bring military learning and college-level outcomes on the same plane, ACE established the Commission on Educational Credits and Credentials (ACE, 2019). ACE recommendations are widely used as a framework in many institutions to award CPL due to the recognition of the fact that military courses are designed in a manner similar to the learning outcomes achieved by college courses. The Military Guide is a collection of all the courses offered by the Army, Navy, Air Force, Coast Guard and Marine Corps. Student veterans can enter the JST number into the ACE Military Guide to identify how many credits they are eligible to receive for their prior training. It has been observed, however, that campuses do not consider ACE recommendations as binding, and hence do not employ them to assess the creditworthiness of a student veterans' transcript. This is observed in the findings of this research.

With existing literature demonstrating the importance of CPL on learning outcomes, it is interesting to observe the process followed to award credit for prior learning. In a report in The Successful Registrar titled "Propel student veterans to degree with a framework to articulate military credit", the PLA framework at the University of West Georgia was discussed and its best practices highlighted (Sutton, 2018). The biggest take-away from the implemented system is that familiarity with military training and courses is needed to assess and ascertain whether credit 
should be granted to the student or not. Because military courses can change versions frequently, the onus falls on campus CPL coordinators to be aware of the differences among versions, especially because once a course has been approved for credit it serves as a precedent to award credits for any incoming student with similar courses (Sutton, 2018). However, the JST is designed to make the assignment of credits easier (Joint Services Transcript, n.d.).

One of the biggest impacts that CPL has, which has not been discussed enough in existing literature, is the waste of public resources that occurs when CPL is not used or maximized. Veterans have military training and their tuition post-service is paid for by the GI bill, both of which are publicly funded. Identifying the double spending costs for the same training is one of the main focus areas of this research. In addition to this, every veteran spending extra time on classes already done in the military is occupying a college seat that could have served another student constituting an "opportunity cost", to borrow an economic construct (National Conference of State Legislatures, 2019). Also, any student who graduates on time or early is a knowledge-addition to the workforce and in turn, contributes to a more productive economy. As the needs of higher education get more complex and individualistic, it is essential for institutions to adapt to this growing diversity and cater to the special needs that arise thereof (Bergman, 2016). Such downstream ramifications caused by the failure of awarding credit for prior training is a missing loop in the extant literature.

Another aspect explored for awarding CPL is the improvement in the morale of students who are able to graduate earlier. Research by Dagavarian \& Walters (1993) shows that students feel accomplished, confident and proud when they have been awarded credits for their military experience, which in turn helps them to map their career path ahead. This leads to students 
feeling connected to the academic world and increases the likelihood of them pursuing a higher degree.

With this limited literature present, the current research intends to contribute to the field of Credit for Prior Learning and to fill any of the aforementioned gaps that the present literature offers. 


\section{METHODOLOGY}

The research methodology used in this project will follow Sylvia and Sylvia's (2012)

managerial audit style of process evaluation. This type of audit aims at identifying problems, initiating organizational change to address it and planning ahead with regards to that specific program.

After reviewing the literature present on this topic, the best approach for the purposes of this project was to identify four campuses within the UC and CSU systems and interview the Articulation Officer (or Implementing Officer, depending on the campus nomenclature) about the process followed for awarding credit for prior learning and military experience. The campuses were chosen with a specific criterion in mind. UC Santa Cruz is considered the "sister" UC campus for San José State University. UC San Diego and San Diego State University were chosen because of their proximity to multiple Naval and Marine Corps bases, leading to a relatively higher population of student veterans.

The interviews were conducted via email and by following a questionnaire prepared in order to maintain consistency among the data being collected. The only in-person interview was conducted with the Articulation Officer of San José State University. The questionnaire sent to the officers is shown in Table A below. 
Table A: Questionnaire mailed to Articulation Officers

\begin{tabular}{|c|l|}
\hline Question number & \multicolumn{1}{c|}{ Question } \\
\hline 1. & $\begin{array}{l}\text { Does the campus award credit for prior learning and if yes, what is the } \\
\text { process followed to do the same? }\end{array}$ \\
\hline 2. & $\begin{array}{l}\text { Are standardized examinations and their results considered as an } \\
\text { evaluative metric in determining the knowledge level of student } \\
\text { veterans? If yes, what are the exams? }\end{array}$ \\
\hline 3. & $\begin{array}{l}\text { Is the ACE Military Guide used to determine the number of credits that } \\
\text { the student is eligible to get? If not, how is the determination made? } \\
\text { Please elaborate. }\end{array}$ \\
\hline 4. & \begin{tabular}{l} 
Is there any extra information you think would be relevant in this study? \\
\hline
\end{tabular}
\end{tabular}

In addition to the interviews, a survey was administered to all the student veterans enrolled with the Veteran Resource Center (VRC) on San José State University campus. This was done to obtain data on the average number of credits received by a student. In addition to this, the MOS of every student was collected to view the ACE recommendation for the same. The MOS and their recommended ACE credits were calculated to point out the difference in number of credits received versus number of credits recommended by ACE. Table B lists the questions in the survey. The complete survey is attached in the Appendix. 
Table B: Student Survey Questions

\begin{tabular}{|c|l|}
\hline Question number & \\
\hline 1. & Which branch of the military did you serve in? \\
\hline 2. & Please identify your gender. \\
\hline 3. & Please identify your ethnicity. \\
\hline 4. & Did you receive credit for any prior training in the military? \\
\hline 5. & If yes, how many credits did you receive? \\
\hline 6. & Please provide your Military Occupation Specialty/ Air Force Specialty \\
& Code. \\
\hline 7. & What was your grade in the military? (E1-E9/Other) \\
\hline
\end{tabular}

The Military Occupational Specialty (MOS) code is a nine-character code used in the United States Army and Marine Corps for a specific job. This can be used as an input in the ACE Guide to determine credits for their training as a part of the job. After the survey, the MOS was used to determine the number of credits for which a student is eligible from his/her military training. This was then compared to the number of credits awarded to them. In addition to the managerial audit, this survey provided additional data on the existing mismatch, if any, between the number of credits for which a student veteran is eligible and the number of credits awarded. According to the IRB definition of "human interaction", any interaction used to collect information about an institutional process does not fall under the category of research involving human subjects because there was no personally identifiable information provided. The IRB certification for this research project was filed under the Exclusion category. 


\section{FINDINGS}

This section will address the results that were discussed in the Methodology and has been divided into two parts. The first part will discuss the findings from the interviews that were conducted with articulation officers from four different campuses from the UC and CSU systems. The second part will focus on the findings obtained from the survey administered to student veterans registered with the Veteran Resource Center at San José State University (SJSU). The survey was sent out on February 14th, 2020 by the Veteran Resource Center at SJSU to 513 students. The survey was active for one month till March 15th, 2020, with weekly reminders sent to students.

Part One: Process Followed to Award Credit for Prior Learning on Selected UC And CSU Campuses

\section{University of California, Santa Cruz}

According to the GI Bill Comparison Tool managed by the Department of Veteran Affairs, there are 249 GI Bill recipients at UC Santa Cruz, and this includes veterans, servicemembers and dependents using the GI Bill (GI Bill Comparison Tool, DoVA, 2020). The latest data on the number of student veterans at UC Santa Cruz is based on the 2018-2019 academic year. There were 79 student veterans enrolled in undergraduate courses and 12 in graduate school, constituting $4 \%$ of the total student population on campus (Undergraduate Outcomes, UC Institutional Research and Academic Planning, 2020).

At UC Santa Cruz, the articulation officer confirmed that credit is offered to veterans for physical training (PE Credit) and additionally, credit for Military Science and Language courses may be offered. This depends entirely on the military transcript and the description of courses in that transcript. The website of the Office of Registrar, UC Santa Cruz briefly mentions "credit 
for prior training” based on evaluation of the military transcript (Office of Registrar, UCSC, 2018). For courses apart from Physical Training, UC Santa Cruz will consult ACE recommendations according to UC guidelines and will not award credit for any college-level standardized exams mentioned above.

\section{University of California, San Diego}

According to the GI Bill Comparison Tool managed by the Department of Veteran Affairs, there are 780 GI Bill recipients at UC San Diego. However, this includes veterans, servicemembers and dependents using the GI Bill (GI Bill Comparison Tool, DoVA, 2020). This campus in the UC system has the third highest number of student veterans enrolled in the year 2018-2019 according to a report published by the University of California Institutional Research and Academic Planning (Undergraduate Outcomes, UC Institutional Research and Academic Planning, 2020). There were 388 students enrolled, 261 in undergraduate courses and 127 in graduate school, constituting $17 \%$ of the total student population.

The articulation officer at UC San Diego said credit is offered to student veterans based on the broad guidelines laid down by the UC system. Credit is awarded for physical training (PE Credit) and additionally, credit for Military Science and Language courses may be offered. This depends entirely on the military transcript and the description of courses in a student's transcript.

\section{San Diego State University}

According to the GI Bill Comparison Tool managed by the Department of Veteran Affairs, there are 1,589 GI Bill recipients at San Diego State University, and this includes veterans, servicemembers and dependents using the GI Bill (GI Bill Comparison Tool, DoVA, 2020). As of Fall 2019, San Diego State University (SDSU) has 671 student veterans in undergraduate 
courses and 160 student veterans enrolled in graduate school, constituting $2.2 \%$ of the total student population (SDSU Veteran Student Profile, 2020).

Based on the correspondence with the articulation officer at SDSU, the campus is guided by the ACE recommendations in granting undergraduate credit for military service. SDSU will award credit for military education, and MOS-based military experience. Credit is given to either lower or upper division units as specified in the ACE recommendations. However, they do not award any credit for vocational, technical or certificate degree category units.

Military basic training credit is awarded for the initial basic training completed when the individual entered the military branch. Basic training credit is dependent upon the completion of the required number of weeks of training. Credit for each branch of military training is determined by the date of entry. So, currently Air Force training receives four credits, Army receives six credits, Coast Guard receives seven credits, Marine Corps receive nine credits and Navy receives two credits (Academic Credit, San Diego State University, 2020).

The university allows a maximum of seventy credits that can be received based on prior learning. In addition to this, standardized tests like CLEP and DSST are recognized by the university. Also, Defense Language Proficiency Test (DLPT), Broadened Opportunity for Officer Selection and Training offered by the Navy, and Platoon Leaders Class are some of the other non-traditional credit accepted by the university. The procedure to obtain credit for military service is to submit a copy of the Joint Service Transcript along with the DD-214 form to the university.

\section{San José State University}

According to the GI Bill Comparison Tool managed by the Department of Veteran Affairs, there are 658 GI Bill recipients at San José State University, and this includes veterans, 
servicemembers, and dependents using the GI Bill (GI Bill Comparison Tool, DoVA, 2020). The Veterans Resource Center on campus has 516 registered student veterans, consisting of 425 undergraduate student veterans and 91 graduate student veterans.

The interview with the articulation officer on campus revealed that the university has an outline for its process of granting Credit for Prior Learning (CPL) for student veterans from military training and experience.

The student fills out a Request for Military CPL and submits it, along with the Joint Service Transcript (JST) and the DD-214 (Certificate of Discharge from Active Duty) to the VRC, which then submits this request and the transcript to the SJSU articulation officer for evaluation. The officer evaluates the courses in the transcript with the help of ACE recommendations, and equates them to SJSU credits. This is referred to the corresponding academic departments to get their approval, or to see whether the credit is to be considered as an elective. The student is then informed of the decision taken by the articulation officer in consultation with the academic department head.

The university does recognize scores from standardized examinations like CLEP and DSST. However, the final decision lies solely with the articulation officer, concerned faculty and the corresponding academic department head. SJSU considers ACE recommendations in awarding credits for military training and courses. A maximum of seventy credits can be awarded to students in lower division and/or upper division courses based on ACE recommendations. Credits are granted to most student veterans for Physical Education (PE; three credits) and General Education (GE; three credits). 


\section{Part Two: Survey Administered to Student Veterans at SJSU}

A survey was administered to the student veterans registered at the Veteran Resource Center (VRC), 516 students in total. The aim of the survey was to get information on the number of credits that a student had received, and calculate the number of credits that student is eligible for based on ACE recommendations for their MOS.

Over the course of this survey, a total of 208 responses were recorded. For a population size of 516 people with a confidence interval of $95 \%$ and a margin error of $5 \%$, the ideal sample size would be 176 responses (Qualtrix Sample Size Calculator, 2020). So, the total responses received exceeds the required minimum. On taking a closer look at the data collected, it was seen that five responses were from military dependents (family of a military service member), four responses from officer rank students who are typically graduate students, and 13 responses had incomplete data. With these removed from the survey responses, the final data has 186 entries $(208-22=186)$ that were considered for analysis. There were four responses from officer-rank veterans. The responses were from student veterans enrolled in graduate courses and have not been included in the current analysis, as ACE recommendations are only for enlisted training outside of an accredited academic institution. 
Table C: Final Student Survey Numbers

\begin{tabular}{|l|r|}
\hline \multicolumn{2}{|c|}{ Numerical representation of survey response } \\
\hline Total responses & 208 \\
\hline Number of incomplete responses & 5 \\
\hline Number of dependents & 4 \\
\hline Officer-level responses (O1-O10) & 22 \\
\hline Total dropped & $\mathbf{1 8 6}$ \\
\hline Total number of valid responses & \\
\hline
\end{tabular}

\section{Basic Demographic Information of Respondents}

a) Military branch

Of the 189 student veterans who took the survey, $17 \%$ were with the Air Force, $35 \%$ belonged to the Army, $1 \%$ served with the Coast Guard, $22 \%$ served with the Marine Corps, and $25 \%$ were Navy service members. Table D provides the individual breakdown of students belonging to different branches of the military and Figure 3 gives the percentage distribution of the same. 
Table D: Distribution based on Military Branch

\begin{tabular}{|l|r|}
\hline \multicolumn{1}{|c|}{ Branch } & \multicolumn{2}{c|}{ Number of students } \\
\hline Air Force & 32 \\
\hline Army & 64 \\
\hline Coast Guard & 1 \\
\hline Marine Corps & 43 \\
\hline Navy & 46 \\
\hline Total & $\mathbf{1 8 6}$ \\
\hline
\end{tabular}

Figure 3: Distribution based on Military Branch

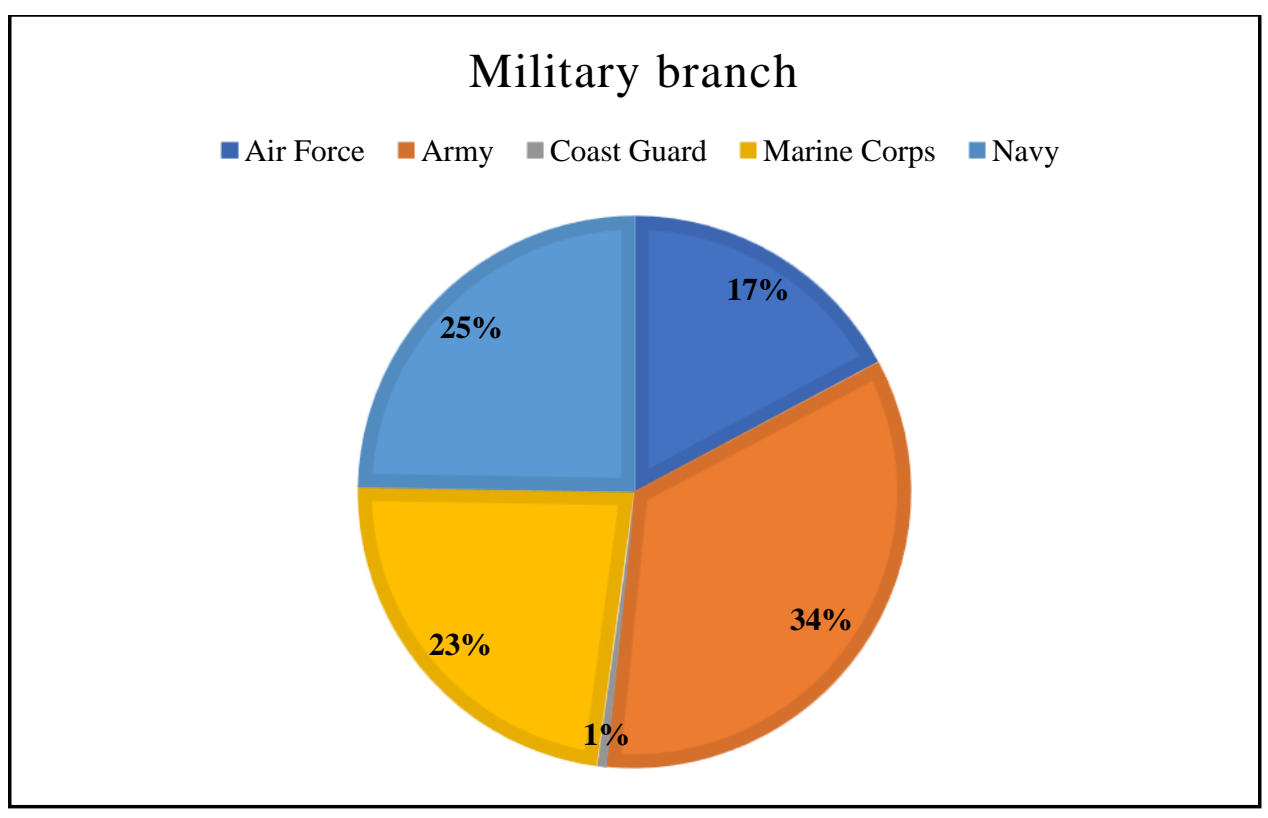

\section{b) Gender}

Males constituted $81 \%$ of the respondents, while females constituted only $19 \%$ of the total sample. Table E and Figure 4 provide a numerical and percentage breakdown, respectively. 
Table E: Distribution by Gender

\begin{tabular}{|l|r|}
\hline \multicolumn{1}{|c|}{ Gender } & $\begin{array}{c}\text { Number of } \\
\text { students }\end{array}$ \\
\hline Female & 35 \\
\hline Male & 150 \\
\hline Don't wish to disclose & 1 \\
\hline Total & $\mathbf{1 8 6}$ \\
\hline
\end{tabular}

Figure 4: Distribution by Gender

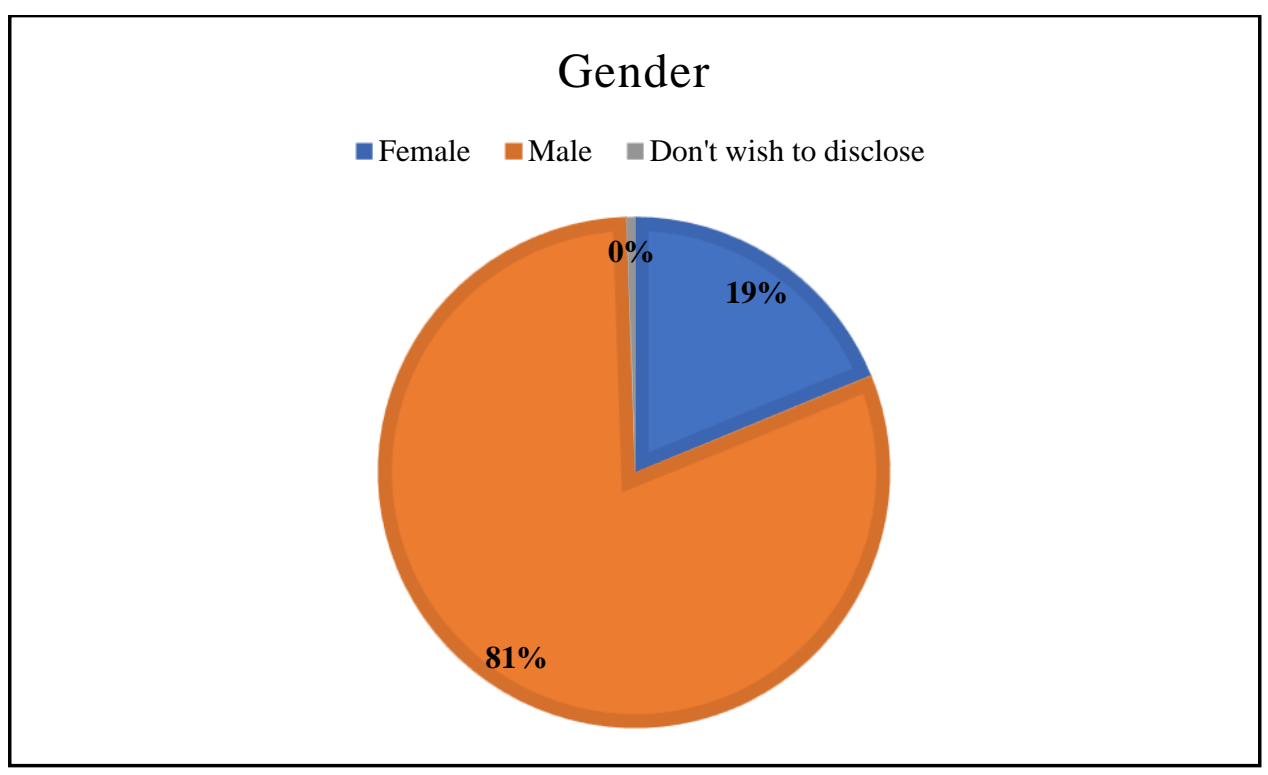

\section{c) Ethnicity}

The numbers based on ethnicity show that the largest ethnic group was Asian respondents, making up $29 \%$ of the total population, while African Americans were the fewest with just $4 \%$ of the respondents. Table F and Figure 5 provide a numerical and percentage breakdown, respectively. 
Table F: Distribution by Ethnicity

\begin{tabular}{|l|r|}
\hline \multicolumn{1}{|c|}{ Ethnicity } & \multicolumn{1}{|c|}{$\begin{array}{c}\text { Number of } \\
\text { students }\end{array}$} \\
\hline Asian & 53 \\
\hline African American & 49 \\
\hline Hispanic & 10 \\
\hline Native Hawaiian/Pacific & \\
\hline Islander & 52 \\
\hline White & 10 \\
\hline Other & 5 \\
\hline Don't wish to disclose & $\mathbf{1 8 6}$ \\
\hline Total & \\
\hline
\end{tabular}

Figure 5: Distribution by Ethnicity

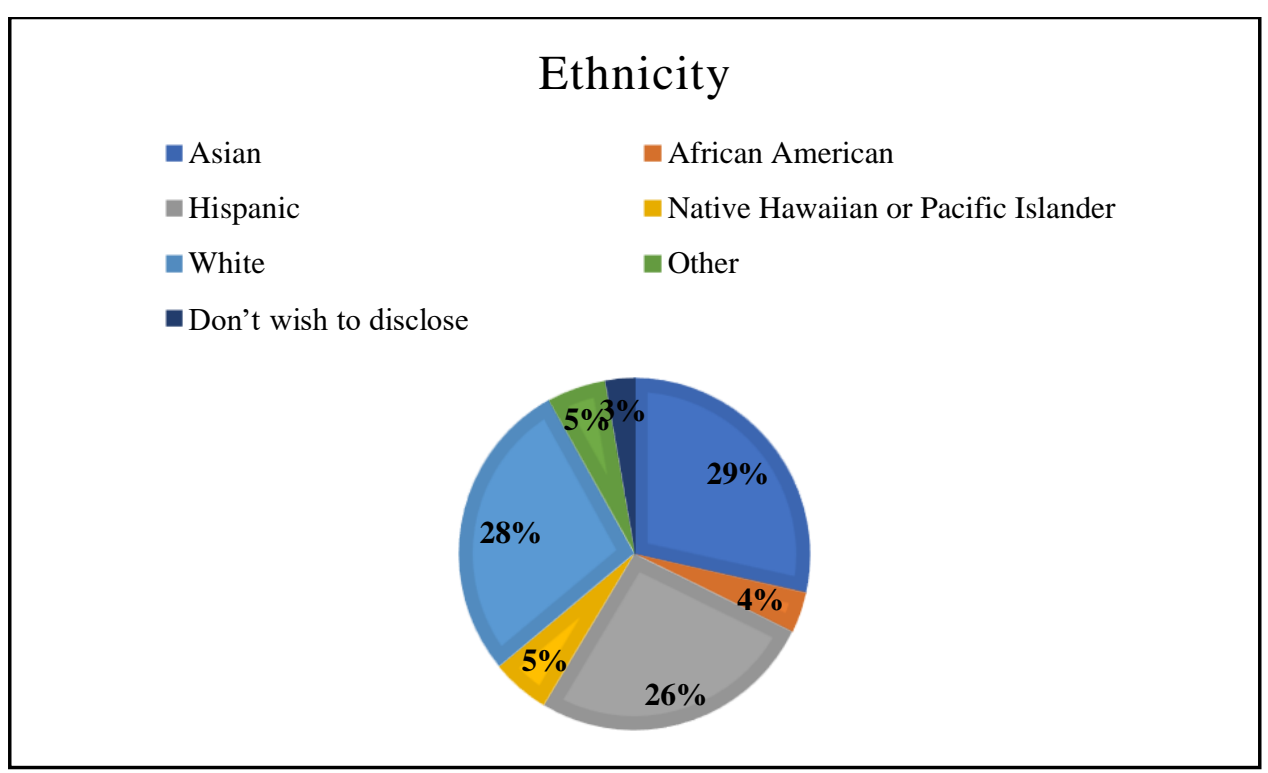




\section{d) Grade in the military (E1-E9):}

ACE made credit recommendations based on the grade held during an individual's tenure in the military. A higher grade elicits greater credits because it means more experience in that position. A majority of the student veterans on campus belong to E4 and E5 grade (almost $80 \%$ of the total responses).

The E4 grade corresponds to Senior Airman (SrA) in the Air Force and the E5 is equivalent of a Staff Sergeant (SSgt). In the Army, Marine Corps and Coast Guard, the E4 and E5 grade correspond to Corporal and Sergeant ranks respectively. In the Navy, E4 and E5 grades are for a Petty Officer Third Class and Petty Officer Second Class respectively.

Table $\mathrm{G}$ and Figure 6 provide the numeric and percentage breakdown respectively, by grade. 
Table G: Distribution by Grade

\begin{tabular}{|l|r|}
\hline \multicolumn{1}{|c|}{ Grade } & Number of students \\
\hline E1 & 1 \\
\hline E2 & 13 \\
\hline E3 & 75 \\
\hline E4 & 75 \\
\hline E5 & 11 \\
\hline E6 & 5 \\
\hline E7 & 0 \\
\hline E8 \& E9 & 5 \\
\hline $\begin{array}{l}\text { Not } \\
\text { specified }\end{array}$ & $\mathbf{1 8 6}$ \\
\hline Total & \\
\hline
\end{tabular}

Figure 6: Distribution by Grade

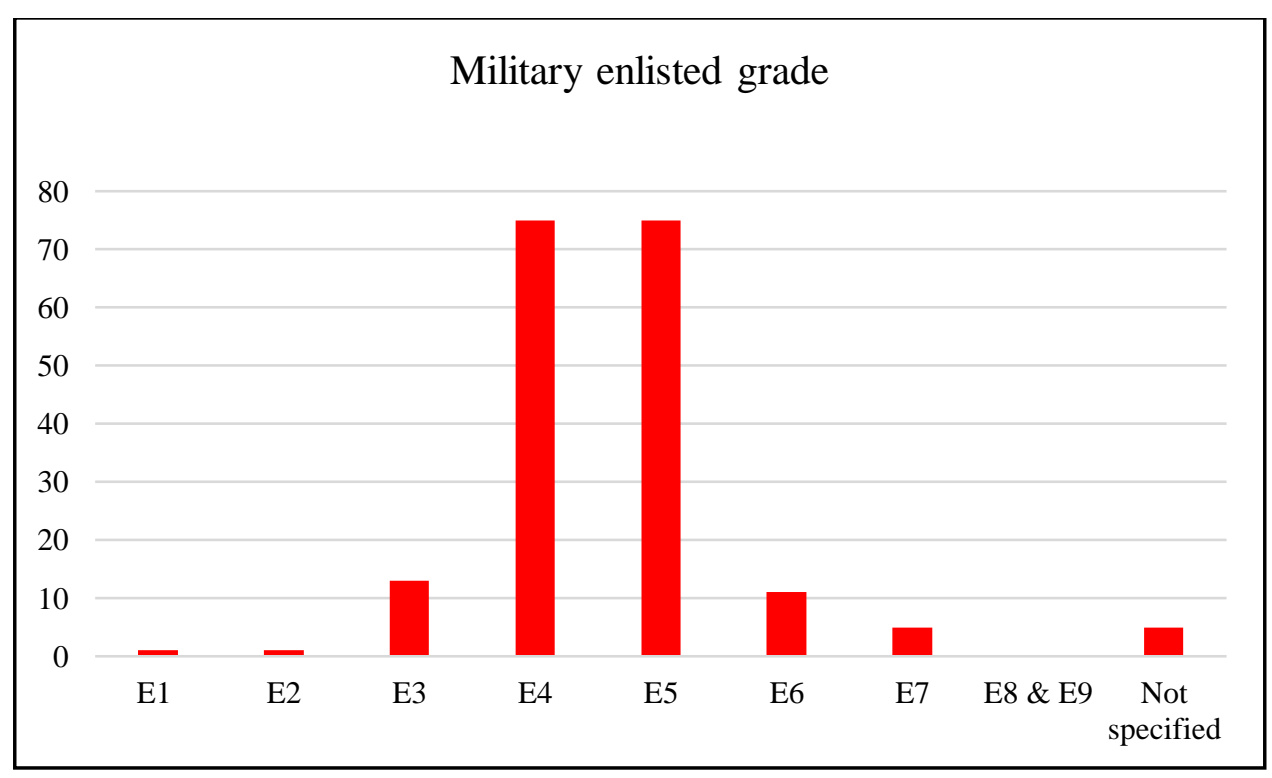




\section{Survey Data Pertaining to Credits}

a) Data on whether a student received credit for prior military learning

The question asked was: "Did you receive credit for prior military training?" and if the answer was yes, they were asked to fill in the next question about how many credits were received. Even though $44 \%$ of students said they received credit for prior training, they were not aware how many credits they received and whether it was already granted. Of the respondents, $33 \%$ indicated that they did not know whether they received credit for prior learning, while $23 \%$ answered "No" to the question. Table $\mathrm{H}$ and Figure 7 provide the numeric and percentage breakdown of the same.

\section{Table H: Number based on credit received}

\begin{tabular}{|l|r|}
\hline \multicolumn{1}{|c|}{$\begin{array}{c}\text { Did you receive credits for } \\
\text { military training? }\end{array}$} & Number of \\
students \\
\hline I do not know & 64 \\
\hline No & 40 \\
\hline Yes & 82 \\
\hline Total & $\mathbf{1 8 6}$ \\
\hline
\end{tabular}


Figure 7: Distribution based on CPL

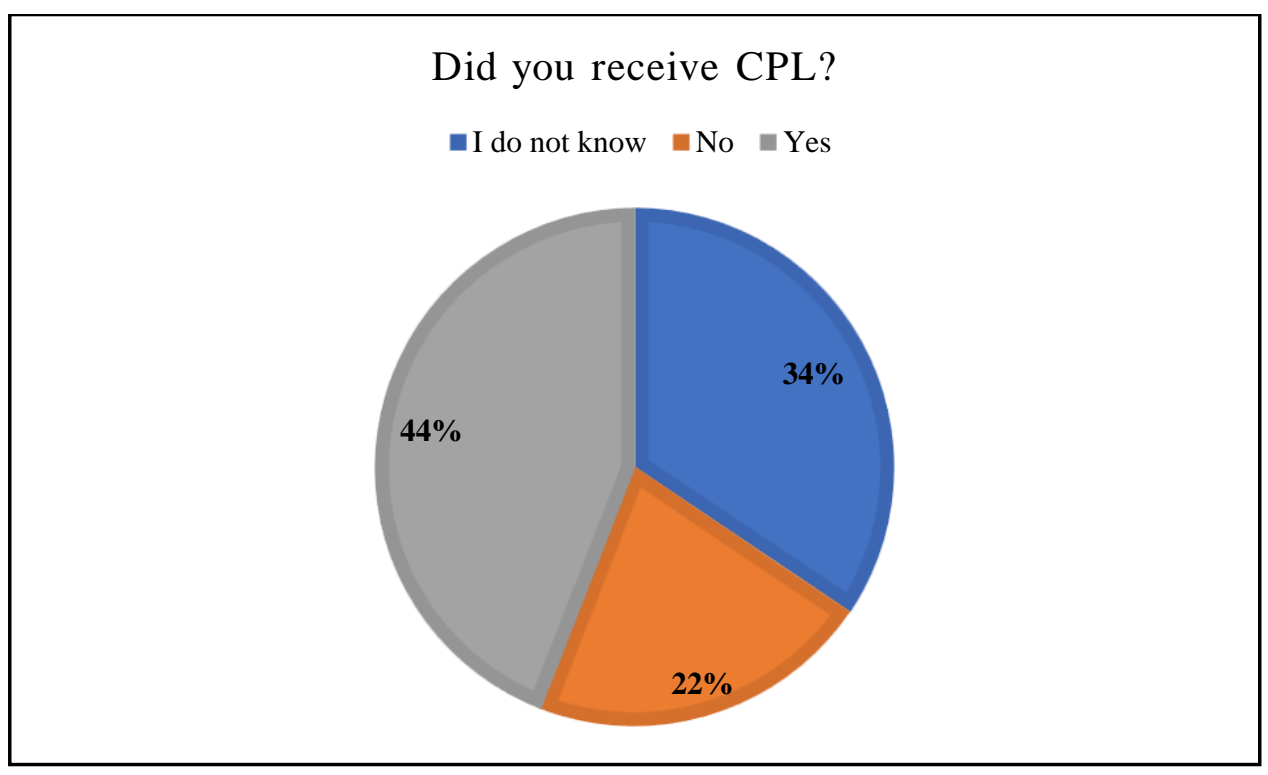

\section{b) Number of credits received versus number of credits recommended by ACE}

This sub-section captures the data on number of credits received by students and the number of credits they are eligible for based solely on their MOS. For ease of presentation, data has been organized based on the branch of military. Each branch has data on the number of credits that a student has received already and then, portrays the number of credits they are eligible to get based on their MOS and ACE recommendations. Air Force does not figure in the analysis because ACE does not list credit recommendations for this branch of military based on MOS. Since Coast Guard had only one entry, that is not included in the following analysis.

The number of credits received will capture data from students who answered "Yes" to the question "Did you receive credit for prior military training?" while the credits based on ACE recommendations will include all students within that branch of military. 
The number of credits from ACE recommendations was calculated based on the MOS provided by the student veteran in the survey. This MOS was entered in the ACE website and corresponding number of credits were recorded. It has to be noted that even for MOS codes that have not been listed in the ACE Military Guide, a student is eligible to get 6 credits for Physical Education (PE) and General Education (GE). So, for MOS entries where the MOS returned no result, the default number of credits awarded is six. In all cases, 6 credits for PE and GE were added to the number of credits recommended by ACE.

Army:

A total of 12 students indicated they received credit for prior learning and nine of those students received up to 6 credits. Table I shows the numerical breakdown of the number of students receiving credits in the intervals specified along with the frequency of students eligible for credits per ACE recommendations and Figure 8 shows the difference in the number of students receiving credit and the number of students eligible for credit per ACE recommendations.

The number of credits as per ACE recommendations that a student can get is calculated using the MOS supplied by the student. This was done for all the students belonging to the Army and as mentioned earlier, PE and GE credits (6 credits) were added to the credits calculated based on the MOS. 
Table I: Number of students receiving credits versus number of students who should have received credits based on ACE recommendations: Army

\begin{tabular}{|c|c|c|}
\hline Number of credits & $\begin{array}{l}\text { Number of students } \\
\text { receiving credits }\end{array}$ & $\begin{array}{c}\text { Number of } \\
\text { students who } \\
\text { should have } \\
\text { received credits } \\
\text { based on ACE } \\
\text { recommendations }\end{array}$ \\
\hline $0-6$ credits & 9 & 58 \\
\hline $7-13$ credits & 2 & 0 \\
\hline $14-20$ credits & 1 & 2 \\
\hline 21-27 credits & $\mathbf{0}$ & 3 \\
\hline 28-34 credits & 0 & 0 \\
\hline $35-41$ credits & 0 & 0 \\
\hline $42-48$ credits & $\mathbf{0}$ & 1 \\
\hline \multicolumn{3}{|c|}{ Additional Information } \\
\hline Individual assessment (6 Credits for PE and GE) & N/A & 5 \\
\hline $\begin{array}{l}\text { No credit for enlisted grade ( } 6 \text { Credits for PE } \\
\text { and GE) }\end{array}$ & N/A & 47 \\
\hline $\begin{array}{l}\text { MOS not listed in ACE (6 Credits for PE and } \\
\text { GE) }\end{array}$ & N/A & 6 \\
\hline
\end{tabular}


Figure 8: Number of students receiving credits versus number of students who should have received credits based on ACE recommendations: Army

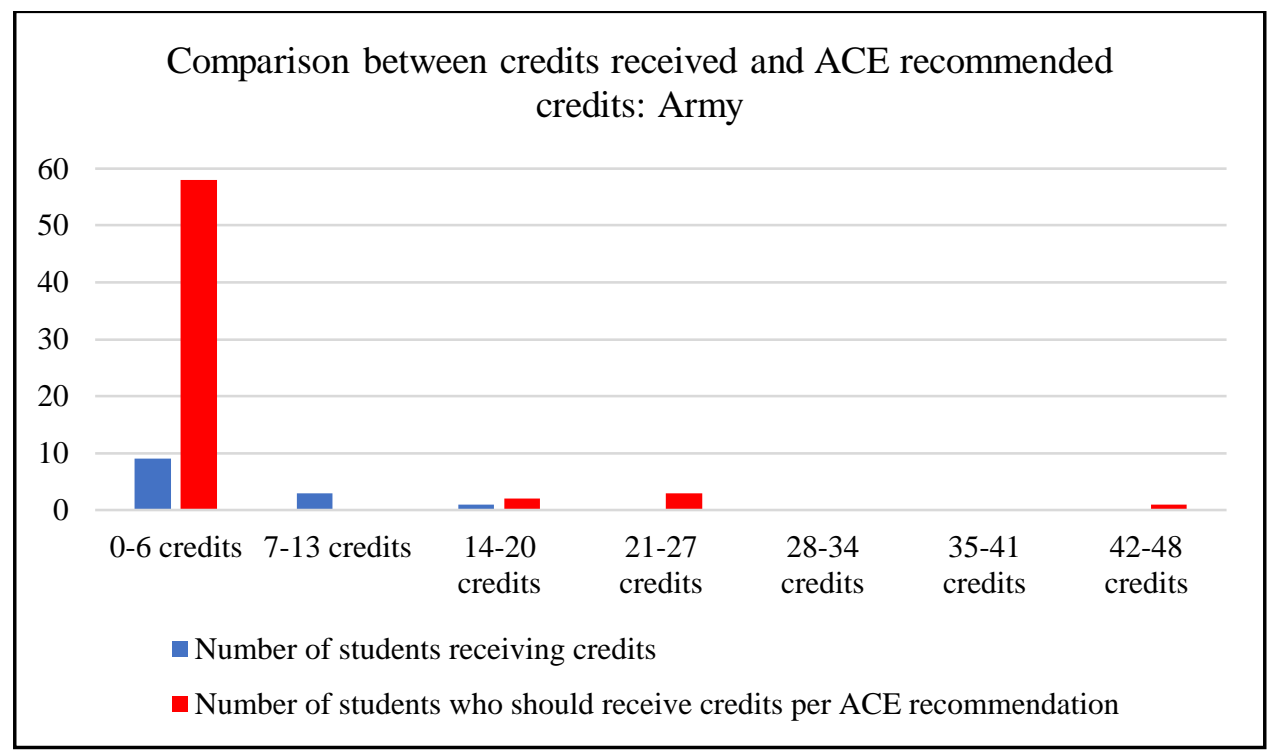

\section{Marine Corps}

A total of 15 students indicated that they received credit for prior learning and 11 of those students received up to 6 credits. Table $\mathrm{J}$ shows the numerical breakdown of the number of students receiving credits in the intervals specified and their corresponding number following ACE recommendations and Figure 9 is a comparison chart showing the distribution of the number of students in the different intervals of credits received.

The number of credits a student was eligible based on ACE recommendations calculated using the MOS supplied by the student. This was done for all the students belonging to the Marine Corps while PE and GE credits ( 6 credits) were added to the credits calculated based on the MOS. 
Table J: Number of students receiving Credits versus number of students who should have received credits based on ACE recommendations: Marine Corps

\begin{tabular}{|c|c|c|}
\hline Number of credits & $\begin{array}{l}\text { Number of students } \\
\text { receiving credits }\end{array}$ & $\begin{array}{c}\text { Number of } \\
\text { students who } \\
\text { should have } \\
\text { received credits } \\
\text { based on ACE } \\
\text { recommendations }\end{array}$ \\
\hline $0-6$ credits & 11 & 36 \\
\hline 7-13 credits & 1 & 1 \\
\hline $14-20$ credits & 2 & 4 \\
\hline $21-27$ credits & 0 & 1 \\
\hline $28-34$ credits & 1 & 1 \\
\hline $35-41$ credits & 0 & 0 \\
\hline $42-48$ credits & 0 & 0 \\
\hline \multicolumn{3}{|c|}{ Additional Information } \\
\hline Individual assessment (6 Credits for PE and GE) & N/A & 0 \\
\hline $\begin{array}{l}\text { No credit for enlisted grade (6 Credits for PE } \\
\text { and GE) }\end{array}$ & N/A & 20 \\
\hline $\begin{array}{l}\text { MOS not listed in ACE (6 Credits for PE and } \\
\text { GE) }\end{array}$ & N/A & 16 \\
\hline
\end{tabular}


Figure 9: Number of students receiving credits versus number of students who should have received credits based on ACE recommendations: Marine Corps

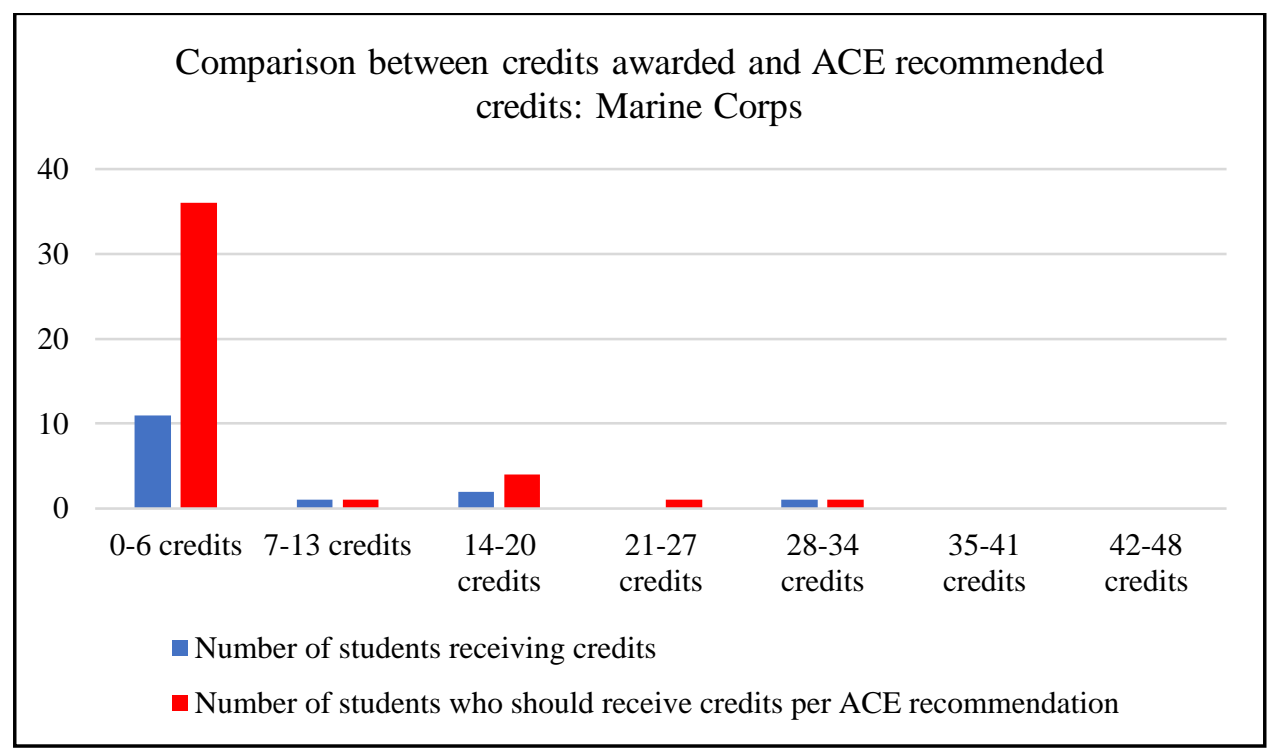

Navy

A total of 21 students indicated that they had received credit for prior learning and 17 students received up to 6 credits. Table K shows the numerical breakdown of the number of students receiving credits in the intervals specified, along with the number of students who can receive credits based on ACE recommendations. Figure 10 is a histogram showing the distribution of the number of students in the different intervals of credits received.

The number of credits that a student was eligible for based on ACE recommendations was calculated using the MOS supplied by the student. This was done for all the students belonging to the Navy, while PE and GE credits (6 credits) were added to the credits calculated based on the MOS. 
Table K: Number of students receiving credits versus number of students who should have received credits based on ACE recommendations: Navy

\begin{tabular}{|c|c|c|}
\hline Number of credits & $\begin{array}{l}\text { Number of students } \\
\text { receiving credits }\end{array}$ & $\begin{array}{c}\text { Number of } \\
\text { students who } \\
\text { should have } \\
\text { received credits } \\
\text { based on ACE } \\
\text { recommendations } \\
\end{array}$ \\
\hline $0-6$ credits & 17 & 10 \\
\hline $7-13$ credits & 4 & 3 \\
\hline 14-20 credits & $\mathbf{0}$ & 10 \\
\hline 21-27 credits & $\mathbf{0}$ & 18 \\
\hline $28-34$ credits & 0 & 3 \\
\hline $35-41$ credits & 0 & 0 \\
\hline $42-48$ credits & 0 & 2 \\
\hline \multicolumn{3}{|c|}{ Additional Information } \\
\hline Individual assessment (6 Credits for PE and GE) & N/A & 0 \\
\hline $\begin{array}{l}\text { No credit for enlisted grade (6 Credits for PE } \\
\text { and GE) }\end{array}$ & N/A & 7 \\
\hline $\begin{array}{l}\text { MOS not listed in ACE (6 Credits for PE and } \\
\text { GE) }\end{array}$ & N/A & 3 \\
\hline
\end{tabular}


Figure 10: Number of student veterans receiving credits versus number of students who should have received credits based on ACE recommendations: Navy

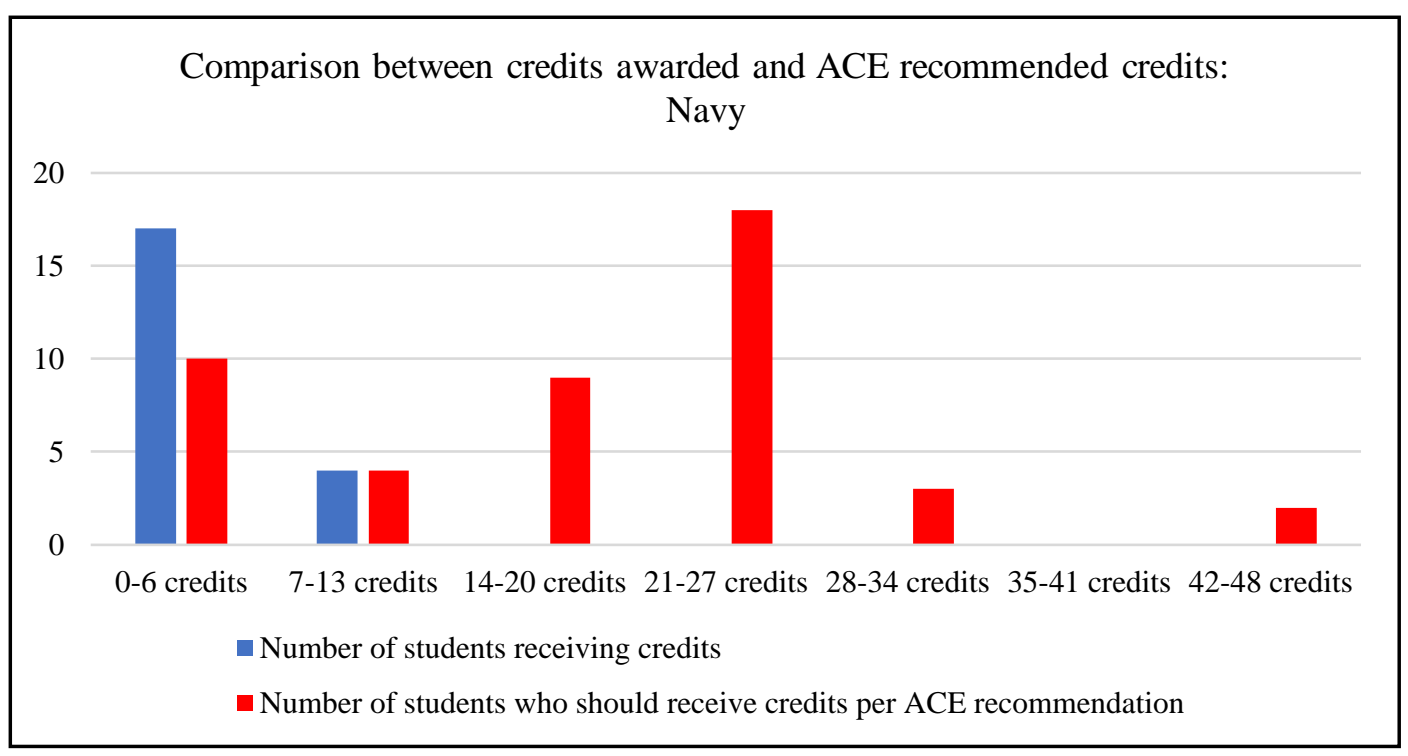




\section{ANALYSIS AND RECOMMENDATION}

This section interprets and discusses the results from the previous section. The goal of this analysis is to provide a clear picture of whether credit for prior learning is being implemented in an effective manner by highlighting the discrepancy, if any, between the credits being awarded to students and the number of credits ACE recommends based on their MOS.

\section{Analysis of UC Policy to Award Credit for Military Training}

University of California schools follow a unified policy to award credit for prior military training. Though there exists no extensive documentation on the exact procedure followed, it is understood that credit is granted to students on a case-by-case basis depending on the JST. The policy states that lower division credits will be awarded to students if an equivalent course exists on that campus. So, the onus falls on each campus to determine whether they recognize a particular military course or not.

UCSD has a higher population of veterans when compared to UCSC and it would be interesting to see the average number of credits being granted to student veterans based on current campus policy. The current need is to develop a policy framework that can better evaluate the ACE recommendations, military training/courses, and equivalent college courses for that training, and ensure that the credits are awarded to shorten the time-to-degree for qualified veteran students.

\section{Analysis of CSU Policy to Award Credit for Military Training}

Based on correspondence with the Articulation Officer at SDSU and an interview with the SJSU Articulation Officer, it is observed that these campuses have devised a system of granting credit for military training that meets their requirements in an effective way. While there is no defined framework or policy established for universities within the CSU system, campuses seem to 
follow a similar pattern, starting with the submission of a candidate's JST and DD-214 form.

Following this, a determination is made on the number of credits granted for PE. SDSU seems to offer different credits based on the length of military training undertaken, and SJSU offers three credits for PE for any student applying to get credit for military training. Both campuses consider ACE recommendations while awarding credit. At SJSU, the department head and concerned faculty are consulted in this process. ACE recommendations are not compulsory/binding and the final decision lies with the department head after considering the learning outcomes listed in the JST. The final decision is completely under the discretion of the academic department head.

More often than not, it has been observed that there is a difference in the course structure of the military and the university. In these cases, it is essential to do an analysis of the topics covered in both syllabi, and take into account the military experience and on-the-job training of the student. This requires knowledge of the military course, MOS of the student and the nature of the job performed. During the course of this research one aspect of the military that stood out is the sheer complexity of the grades, jobs performed while in service and how this influences the learning of a service member.

The inherent complexity of understanding military courses, and training and translating them to credits in a university setting needs a dedicated office that has staff who specialize in this area. Experienced staff could serve as an intermediary between the Articulation Officer and the VRC. Staff who are well-versed in reading a JST and understanding the type of job/training a candidate might have performed, and translating the same into college-level credit, is of utmost importance. A knowledgeable workforce could contribute significantly towards designing an efficient system that achieves the best possible outcome. 


\section{Analysis of Survey Results}

On the question "Did you receive credit for prior military training?", $44 \%$ of students answered "Yes", but most of them were unable to provide the number of credits they did receive. Moreover, $33 \%$ of students answered "I don't know" to the question. This points to a huge number of students who are unaware that they are eligible to apply for credits and thereby, shorten the time period of their college degree.

In order to increase awareness among student veterans, the Veteran Resource Center in conjunction with the Articulation Officer can educate students on the various ways credit for prior military training/course can be obtained. This can be done by conducting an orientation session with the student veterans on the first day of the semester. This session can highlight the various ways of attaining credit for prior military training and courses. Students should be made aware of the avenues available to them and the VRC could help them map out their path forward with the same. This could increase the number of students applying and appealing for credits.

There is another factor that could cause student veterans to not apply for prior learning credit, and that could be attributed to students making the most of the GI Bill coverage. The coverage pays for a student's tuition, housing, books and travel while the university atmosphere provides them with a stable environment before transitioning into a civilian workforce. Student veterans may want to take advantage of their college learning before stepping into the workforce that would admittedly be different from their military experience. This is just a working hypothesis and future research can study the motivation or the lack thereof, among student veterans applying for credit for prior training. It is likely, however, that many veterans are not aware of the ability to earn credits from their military training, or the ability to use the GI Bill to obtain additional education within or after a BA/BS, such as a graduate degree, a certification 
(such as for teaching or certified public accountant), or even additional academic training in a second major or a minor. An educational program by the VRC could explain these options for maximizing the personal benefits of available GI Bill funds, which might encourage veterans to obtain the maximum CPL credits from their MOSs.

The next set of analyses is based on military grade and the reason for its inclusion in the survey. Over $79 \%$ of students belonged to E4 and E5 grade in the military. ACE recommendation for credits based on MOS takes into account the number of years of service at a particular occupation. This is the reason survey respondents were asked to fill out their grade in the military. It helped the researcher ascertain if they were eligible for credit or not. Many MOS codes are eligible to receive credit only if they are of E6 rank or higher (Staff Sergeant or higher) or in the case of Army, they need to be of Skill Level 30 or more to be eligible for credits. A total of 74 respondents' MOS fell in this category. Their MOS was not eligible for credit based on their grade at the end of service (ACE, 2019). It is important to understand why this limitation was placed on some MOSs, so more information should be provided in the Military Guide to assist veterans in making decisions about remaining in the service an working toward a higher rate.

Another factor that stood out while analyzing the results was the presence of certain MOS that were not listed as a part of the ACE Military Guide. These MOS codes have either been reclassified, or they are not recognized for credits by ACE. Twenty-five respondents' MOS were not listed on the online Military Guide. While the job description for the omitted MOS codes were found on the respective military branch websites, the reason for their omission from the online guide is not known. The Military Guide should explain why some MOs cannot be calculated for JST credit. 
The third set of results were Individual Assessment of skillsets and knowledge for certain MOS codes. In these cases, ACE does not recommend a defined number of credits, but leaves it up to the concerned universities to determine the skill level of a candidate. This is done because the time spent on a particular job varies from individual to individual and so does the corresponding on-the-job training. The Military Guide should provide more details about the variances that impact credits awarded.

So, while determining the number of credits that a student is eligible for based on the ACE recommendations, a total of six credits is added to the number of credits received from the ACE Military Guide. This is because currently SJSU awards a total of six credits to a student veteran towards their PE and GE for any honorable military service.

The comparison of credits received versus number of credits students are actually eligible to receive based on the ACE recommendations shows a huge difference in the student receiving credit and those who do not. In the case of the Army, there are 12 students currently who have received credit for prior military training/courses. However, using the ACE recommendations based on MOS, 65 students are eligible to receive credits. The minimum that every student can receive is six credits (for PE and GE) and the maximum in this case is between 42 to 48 credits. Similarly, in the Marine Corps there are 15 students who are currently receiving credit as opposed to the 64 students who are eligible to receive credit. Of all the branches of military, more students from the Navy are receiving credits than any other branch. There are 21 students from the Navy who are receiving credit, and 46 students could receive credit if ACE recommendations are taken into consideration.

Based on the numbers received from the survey, it would seem that a greater number of Navy student veterans are receiving credits for prior training, while Army student veterans are on 
the other end of the spectrum. The numbers show a significant disparity between the number of students receiving credits and the number of students who should be eligible for credit based on ACE recommendations for their MOS. This signals a gap in the system of awarding credit because students are either unaware of it or they do not understand the process involved in getting these credits. This kind of system places the onus on the students to understand the process and subsequently, decipher the number of credits they are eligible for.

The hidden cost in this scenario is the taxpayer money being needlessly used to pay the fees of the student veterans via the GI bill when those credits were already earned through training during military service. Public university systems like the UC and CSU need to take an active role in ensuring that this kind of double spending is avoided. They need to collaborate with the Department of Veteran Affairs, the VRC, and the students in designing a system for granting credit that will benefit all the concerned parties equally, and spend taxpayer dollars wisely. A speedier time from matriculation to graduation enabled by awarding proper credit would raise the university's graduation rate for student veterans, as their time to degree could be shortened, or their academic career could be enriched by a minor, a major, a certificate or an advanced degree. 


\section{CONCLUSION}

Credit for Prior Learning is an area where dynamic policy revision is needed as larger numbers of veterans return from war fighting to civilian occupations. The findings from this research, coupled with the existing literature, demonstrate the importance of having a robust system of translating military training and courses into university-level credit. UC and CSU systems are pioneers in undergraduate and graduate education in California and a policy to recognize military training/courses in these campuses can set the base for other educational institutions to follow. With the GI Bill being funded ultimately by the taxpayers, it is of utmost importance to use this fund judiciously and towards achieving the original intent of the 1944 Servicemen Readjustment Act. This research was intended to point out the systemic gap existing in recognizing the military credit and its subsequent translation into college credits. The development of a unified policy for the CSU system would ensure recognition and evaluation of the maximum number of military courses and MOS codes, leading to an increased number of students receiving credits and thereby, fast-tracking their progress to graduation. As stated by Dagavarian (1993), when students are recognized and granted credit for prior learning, it increases their feeling of being connected to the academic world and therefore, the likelihood of them pursuing a higher degree is greater.

This research has provided evidence from one large CSU campus that there exists a need for a policy to better address the discrepancy between credits awarded versus ACErecommended credits. This would support an initiative for California universities to establish a common policy framework to award Credit for Prior Learning similar to the MCMC initiative (Multi-state Collaborative on Military Credit, MHEC, 2014). 


\section{REFERENCES}

Airman Vision. (n.d.). Air Force Tech School. Retrieved from https://www.airmanvision.com/air-force-tech-school

American Council on Education. (2019). Military Evaluations. Retrieved from https://www.acenet.edu/Programs-Services/Pages/Credit-Transcripts/MilitaryEvaluations.aspx

Bergman, M., \& Herd, A. (2017). Proven leadership = college credit: Enhancing employability of transitioning military members through prior learning assessment. Advances in Developing Human Resources, 19(1), 78-87. doi:10.1177/1523422316682949

Department of Veterans’ Affairs. (2020). GI bill comparison tool. Retrieved from https://www.va.gov/gi-bill-comparison-tool/profile/11106005

Fonte, L. F. (2008). Prior learning assessment: What price PLA? the financial implications to the institution of awarding credit for prior learning assessment. The Journal of Continuing Higher Education, 56(1), 64-65. doi:10.1080/07377366.2008.10400146

Go Coast Guard. (n.d.). Advance through training as a Coast Guard member. Retrieved from https://www.gocoastguard.com/active-duty-careers/enlisted-opportunities/advancethrough-training

Hoover, E. (2010). Where life earns credit: 'prior learning' gets a fresh assessment. The Chronicle of Higher Education, 56(28)

Jackson, A. (2016). Credit For Prior Learning: The Efficacy Of Awarding Credit For NonCollege Learning On Community College Completion. Retrieved from: ProQuest Dissertations Publishing. 
Joint Services Transcript. (n.d.). Joint Services Transcript FAQ. Retrieved from: https://jst.doded.mil/faq.html

Leiste, S. M., \& Jensen, K. (2011). Creating a positive prior learning assessment (PLA) experience: A step-by-step look at university PLA. International Review of Research in Open and Distance Learning, 12(1) doi:10.19173/irrodl.v12i1.898

Marines: The official website of US Marine Corps. (n.d.). Training and Education Command. Retrieved from https://www.candp.marines.mil/Organization/SupportingEstablishment/Training-and-Education-Command-TECOM/

Marine Corps University. (n.d.). CEME Schools and Course Descriptions. Retrieved from https://www.usmcu.edu/ceme/courses/

MICMVE. (n.d.). Military equivalency. Retrieved from https://micmve.org/wpcontent/uploads/military-equivalency/digital-resources/skill-level-pay-grade-and-rankdef.pdf

Mid-Western Higher Education Compact. (2020). Multi-state collaborative on military credit. Retrieved from https://www.mhec.org/policy-research/multi-state-collaborative-militarycredit/mcmc-resources

Mid-Western Higher Education Compact. (n.d.). Multi-State Collaborative on Military Credit. Minneapolis: MHEC. Retrieved from https://www.mhec.org/sites/default/files/resources/MCMC_1pgsummary_0.pdf Military One Source. (2019). The Joint Services Transcript for Military Personnel. Retrieved from https://www.militaryonesource.mil/education-employment/for-servicemembers/preparing-for-higher-education/the-joint-services-transcript-for-militarypersonnel 
Military.com. (n.d.). Navy SMART replaced by the Joint Service Transcript. Retrieved from https://www.military.com/education/timesaving-programs/sailor-marine-americancouncil-education-registry-transcript.html

Military Benefits.info. (2020). 2020 Military Pay Charts. Retrieved from https://militarybenefits.info/2020-military-pay-charts/

Multi State Collaborative on Military Credit. (2016). Valuing military learning: A guide to military prior learning assessment and more. Washington DC: CAEL. Retrieved from https://www.mhec.org/sites/default/files/resources/20160803MCMC_Guide_to_Mil itary_PLA.pdf

National Conference of State Legislatures. (2019). Credit for Prior Learning. Retrieved from: https://www.ncsl.org/research/education/credit-for-prior-learning.aspx

Office of Registrar, UC Santa Cruz. (2020). Transfer of credit: Office of registrar. Retrieved from https://registrar.ucsc.edu/navigator/section1/veterans/transfer.html

Orcutt, V. (2018). Prior Learning Assessment For Credit At The University Of Central Missouri: A Program Evaluation. Retrieved from: ProQuest Dissertations Publishing.

Pryor, C. S. (2012). Recognition of prior learning: Credit transfer for enrolled nurses studying science in the Bachelor of Nursing program. Australian Journal of Advanced Nursing, 30(2), 40.

Qualtrics. (2020). Sample size calculator. Retrieved from https://www.qualtrics.com/blog/calculating-sample-size/

Rust, D. Z., \& Ikard, W. L. (2016). Prior learning assessment portfolio completion: Improved outcomes at a public institution. The Journal of Continuing Higher Education, 64(2), 94100. doi:10.1080/07377363.2016.1177871 
San Diego State University. (2019-2020). University policies. California: San Diego State University. Retrieved from https://curriculum.sdsu.edu/curriculum-services/generalcatalog/19_20_gc/139-Uni-Policies.pdf

San Diego State University. (2020). Academic credit. Retrieved from https://arweb.sdsu.edu/es/veterans/ac.html\#credit

Stevens, K., Gerber, D., \& Hendra, R. (2010). Transformational learning through prior learning assessment. Adult Education Quarterly, 60(4), 377-404. doi:10.1177/0741713609358451

Stoval, Q. (2018). Does Tech School start right after Air Force Basic Training?. Retrieved from https://work.chron.com/tech-school-start-right-after-air-force-basic-training-14384.html

Students Veterans of America (SVA). (n.d.). National veteran education success tracker. Washington DC: Students Veterans of America (SVA). Retrieved from https://nvest.studentveterans.org/wpcontent/uploads/2017/02/NVEST_Factsheets.pdf

Sutton, H. (2018). Propel student-veterans to degree with framework to articulate military credit. Successful Registrar, 17(12), 1-7. doi:10.1002/tsr.30392

Sutton, H. (2019). Help student-veterans earn PLA credit on your campus. The Successful Registrar, 18(12), 5. doi:10.1002/tsr.30556

The California State University. (2020). Systemwide admission eligibility and/or baccalaureate credit awarded for external examinations, experiential learning, and instruction in noncollegiate settings; executive order (EO) 1036. Retrieved from https://calstate.policystat.com/policy/7570334/latest/

Today's Military. (n.d.). Enlisting in the military. Retrieved from https://www.todaysmilitary.com/joining-eligibility/enlisting-military 
University of California. (Aug 2018). Statement of transfer credit practices. (n.d.). California:

University of California. Retrieved

from https://admission.universityofcalifornia.edu/counselors/files/Transfer_Credit_Practi

ce.pdf

University of California. (March 2020). UC Institutional Research and Academic Planning.

Retrieved from https://www.ucop.edu/institutional-research-academic-planning/_files/ucstudent-veteran-community.pdf

US Air Force. (n.d.). Basic Military Training Overview. Retrieved from

https://www.airforce.com/education/military-training/bmt

US Army: Go Army Ed. (2017). College credit for MOS/Training. Retrieved from https://www.goarmyed.com/public/public_programs_servicescollege_credit_for_mos.aspx\#Evaluates\%20Military\%20Training\%20for\%20Credit

US Navy. (n.d.). Recruits. Retrieved from https://www.bootcamp.navy.mil/recruits.html

US Department of Veterans Affairs. (2019). Department of Veterans Affairs: GI bill. Retrieved from https:/www.va.gov/education/about-gi-bill-benefits/post-9-11/

Whinnery, E. (Aug 2018). Opening credits: An introduction to PLA policies. Retrieved from https://www.ecs.org/wp-content/uploads/Opening-Credits-An-Introduction-to-PLAPolicies.pdf 


\section{APPENDIX}

\section{Survey instrument at the Veterans Resource Center, San José State University, Spring} 2020

1. Which branch of the military did you serve in?
a. Air Force
b. Army
c. Coast Guard
d. Marine Corps
e. Navy
f. Other (Enter text)

2. Please identify your gender.
a. Male
b. Female
c. Do not wish to disclose
d. Other (Enter text)

3. Please identify your ethnicity.
a. African American
b. Alaskan Native
c. Asian
d. Hispanic
e. Native Hawaiian or Pacific Islander 
f. Do not wish to disclose

g. Other (Enter text)

4. Did you receive credit for any prior training in the military?
a. Yes
b. No
c. I don't know

5. How many credits did you receive? (Please enter a number)

6. Please provide your Military Occupation Specialty (MOS) code/ Rate/ Air Force Specialty Code (AFSC) in the box below.

7. What was your Grade in the military?
a. E1
b. E2
c. E3
d. E4
e. E5
f. E6
g. E7
h. E8
i. E9
j. Other (Enter text) ---------------------- 